\title{
Iron stores in regular blood donors in Lagos, Nigeria
}

This article was published in the following Dove Press journal:

Journal of Blood Medicine

7 June 2013

Number of times this article has been viewed

\section{Adewumi Adediran' \\ Ebele I Uche ${ }^{2}$ \\ Titilope A Adeyemo' \\ Dapus O Damulak ${ }^{3}$ \\ Akinsegun A Akinbami ${ }^{4}$ \\ Alani S Akanmu' \\ 'Department of Hematology and Blood Transfusion, University of Lagos, Lagos, Nigeria; ${ }^{2}$ Department of Hematology and Blood Transfusion, Lagos University Teaching Hospital, Lagos, Nigeria; ${ }^{3}$ Department of Hematology and Blood Transfusion, Jos University Teaching Hospital, Jos, Nigeria; ${ }^{4}$ Department of Hematology and Blood Transfusion, Lagos State University, Ikeja, Nigeria}

Correspondence:Adewumi Adediran Department of Haematology and Blood Transfusion, Faculty of Clinical Sciences, College of Medicine, University of Lagos, PMB 12003, Surulere, Lagos Nigeria

Email adediranadewumi@yahoo.com
Background: Apart from challenging the bone marrow to increase its red cell production, thereby producing more blood for the donor, regular blood donation has been shown to have several benefits, one of which is preventing accumulation of body iron which can cause free radical formation in the body. This study was carried out to assess body iron stores in regular blood donors.

Methods: A total of 52 regular (study) and 30 first-time (control) volunteer blood donors were studied prospectively. Twenty milliliters of venous blood was drawn from each subject, $5 \mathrm{~mL}$ of which was put into sodium ethylenediamine tetra-acetic acid specimen bottles for a full blood count, including red blood cell indices. The remaining sample was allowed to clot in a plain container, and the serum was then retrieved for serum ferritin, serum iron, and serum transferrin receptor measurement by enzyme-linked immunosorbent assay.

Results: Mean hemoglobin and packed cell volume in the study group $(13.47 \pm 2.36 \mathrm{~g} / \mathrm{dL}$ and $42.00 \pm 7.10$, respectively, $P=0.303$ ) were not significantly higher than in the control group (12.98 $\pm 1.30 \mathrm{~g} / \mathrm{dL}$ and $39.76 \pm 4.41$, respectively, $P=0.119)$. Mean serum ferritin was $102.46 \pm 80.26 \mathrm{ng} / \mathrm{mL}$ in the control group and $41.46 \pm 40.33 \mathrm{ng} / \mathrm{mL}$ in the study group $(P=0.001)$. Mean serum ferritin for women in the study group $(28.02 \pm 25.00 \mathrm{ng} / \mathrm{mL})$ was significantly lower than for women in the control group $(56.35 \pm 34.03 \mathrm{ng} / \mathrm{mL}, P=0.014)$. Similarly, men in the study group had a lower mean serum ferritin $(48.57 \pm 45.17 \mathrm{ng} / \mathrm{mL})$ than men in the control group $(145.49 \pm 87.74 \mathrm{ng} / \mathrm{mL}, P=0.00)$. The mean serum transferrin receptor value was higher in the study group $(1.56 \pm 0.88 \mu \mathrm{g} / \mathrm{mL})$ than in the control group $(1.19 \pm 0.38 \mu \mathrm{g} / \mathrm{mL}, P=0.033)$.

Conclusion: These findings suggest that hemoglobin concentration, packed cell volume, and serum iron levels are not significantly affected by regular blood donation and that regular blood donors appear to have reduced iron stores compared with controls.

Keywords: blood donors, hemoglobin, serum ferritin, serum iron, transferrin receptors

\section{Introduction}

Regular blood donation has been found to be beneficial for many reasons. Apart from challenging the bone marrow such that hemopoietic activity is sustained and marrow remains red with continuous production of red cells, regular blood donation prevents accumulation of iron which can cause formation of free radicals in the body. ${ }^{1}$

Important in the pathophysiology of diseases such as diabetes and cardiovascular disorders, is having iron available to participate in free radical reactions. This stems from the ease with which iron is reversibly oxidized and reduced. This property is 
essential for metabolic function, but makes iron potentially hazardous because of its ability to generate powerful oxidant species, such as hydroxyl radicals. ${ }^{2}$

Iron plays a catalytic role in the Haber-Weiss reaction ${ }^{2}$ that leads to generation of superoxide anions, hydrogen peroxide, and hydroxyl radicals. ${ }^{2}$ These oxidants can also trigger release of catalytic iron, initiating a vicious cycle that leads to formation of more reactive oxygen species. ${ }^{2}$

In 1981, Sullivan first postulated the "iron hypothesis", stating that chronic iron depletion has a protective effect against ischemic heart disease and may account for the lower risk of cardiovascular events in menstruating women., 34 Because of its role in promoting lipid peroxidation, accelerated development of atherosclerosis has been postulated as a potential mechanism by which iron overload may increase the risk of ischemic cardiovascular events. In vitro studies have shown that iron acutely promotes platelet reactivity ${ }^{5}$ and iron chelation inhibits activation of tissue factor. ${ }^{6}$ Elevated body iron stores were associated with an increased risk of myocardial infarction in a large cohort of Finnish men. ${ }^{7}$ Iron may also have deleterious effects on vascular function by increasing reactive oxygen species locally, decreasing the bioavailability of nitric oxide, impairing vasorelaxation, and promoting platelet adhesion and aggregation. ${ }^{8}$ Zheng et al provided evidence in support of the Sullivan hypothesis when they found that high frequency blood donors have decreased levels of serum ferritin (a marker of body iron stores), decreased levels of serum 3-nitrotyrosine (a marker of oxidative stress), and greater flow-mediated dilation in the brachial artery (a marker of vascular function). ${ }^{9}$ In another study, it was interesting to note that iron chelation with deferoxamine improved endothelial function in patients with coronary artery disease. ${ }^{10}$

A Canadian study reported an increased risk of myocardial infarction in subjects from the highest serum iron category. ${ }^{11}$ Another report by Kiechi et al from Italy found a positive association between serum ferritin levels and ultrasound measures of progression of carotid atherosclerosis over a five-year follow-up period. ${ }^{12}$

The present study assessed body iron stores in regular blood donors. If an inverse relationship exists between regular donation and body iron stores, then regular blood donation may be advantageous in reducing total body iron stores and indirectly reducing the risk of cardiovascular events. This would indeed be a welcome addition to the many advantages of regular blood donation and could be used as a campaign tool to recruit potential blood donors and help to ameliorate the shortage of blood experienced in transfusion services, especially in our environment, where voluntary donation is for the most part, a myth, as well as enhancing the well-being of regular donors.

\section{Materials and methods}

A total of 52 regular (study) and 30 first-time (control) volunteer blood donors from the Lagos University Teaching Hospital donor clinic were studied. Ethical approval was obtained from the ethics committee of the Lagos University Teaching Hospital.

The study participants consisted of all blood donors over 18 years of age who had donated blood at least twice in the previous 12 months, four times in the previous 24 months, or at least six times in the previous 36 months, and gave their informed consent. Suitable donors donating for the first time were recruited as controls. Regular blood donors who refused to provide consent, pregnant and lactating women, and regular blood donors with a history of diabetes mellitus and cardiovascular disease were excluded from participation in the study.

\section{Specimen collection and preparation}

Blood was collected after recording of the relevant information, including age, gender, history of blood donation, and history of hypertension and/or diabetes mellitus, in a questionnaire. First, $20 \mathrm{~mL}$ of venous blood was drawn from each subject, of which $5 \mathrm{~mL}$ was put into a sodium ethylene diamine tetra-acetic acid (EDTA) specimen bottle for a full blood count, including red blood cell indices, using a KX $21 \mathrm{~N}$ hematology analyzer (Sysmex Corporation, Kobe, Japan). This was analyzed within two hours of collection. The remaining $15 \mathrm{~mL}$ of blood was transferred to a plain screw-capped disposable plastic tube and allowed to stand at room temperature for about two hours until clotted, at which time the clot was retracted. This was then centrifuged, and the serum was then separated, transferred to plain cryotubes using a transfer pipette, and stored at $-72^{\circ} \mathrm{C}$ until analysis. This was used to measure serum ferritin, serum iron, and serum transferrin receptor levels. Serum ferritin and serum transferrin receptor levels were determined by enzymelinked immunosorbent assay. A commercial ferritin assay kit manufactured by Biotech Clinical Laboratories Inc (Novi, MI, USA) was used to determine serum ferritin, a commercial human enzyme-linked immunoassay kit (MyBioSource, San Diego, CA, USA) was used to measure serum transferrin receptor levels, and a commercial iron assay kit (Roche Diagnostics GmbH, Mannheim, Germany) was used to determine serum iron. 


\section{Statistical analysis}

The data were analyzed using Statistical Package for the Social Sciences for Windows version 11.5 software (SPSS Inc, Chicago, IL, USA) and Microsoft Excel. Descriptive statistics, the $\chi^{2}$ test, and the Student's $t$-test were used as appropriate. The critical level of statistical significance was set at $P<0.05$.

\section{Results}

\section{Demographic characteristics}

A total of 82 subjects aged 19-59 years were enrolled, of whom 52 were regular blood donors (study group) and 30 were first-time donors (control group). As shown in Table 1, the subjects were grouped into eight age cohorts. The mean age was $35.19 \pm 7.94$ years in the study group and $33.77 \pm 9.15$ years in the control group $(P=0.461)$. There were 34 men and 18 women in the study group and 16 men and 14 women in the control group.

Table 2 shows the mean hemoglobin, packed cell volume, serum iron, mean serum ferritin, and mean serum transferrin receptor values according to gender. As expected, men had higher mean hemoglobin and packed cell volume $(13.80 \pm 1.69 \mathrm{~g} / \mathrm{dL}, 42.57 \% \pm 5.61 \%)$ than women $(12.48 \pm 2.30 \mathrm{~g} / \mathrm{dL}, 39.00 \% \pm 6.66 \%)$ and the difference was statistically significant $(P=0.004$ and $P=0.011$, respectively). There were no significant differences in the means for red cell indices between men and women. Mean serum iron in the men $(12.26 \pm 4.20 \mu \mathrm{m} / \mathrm{L})$ was higher than in women $(10.34 \pm 3.64 \mu \mathrm{m} / \mathrm{L})$ and this difference was statistically significant $(P=0.042)$. Mean serum ferritin levels were also significantly higher in men $(78.24 \pm 75.40 \mathrm{ng} / \mathrm{mL})$ than in women ( $40.41 \pm 32.13 \mathrm{ng} / \mathrm{mL}, P=0.009)$. Comparison of mean serum transferrin receptor levels showed no difference between the genders $(1.39 \pm 0.52 \mu \mathrm{g} / \mathrm{mL}$ in men and $1.47 \pm 1.04 \mu \mathrm{g} / \mathrm{mL}$ in women, $P=0.650$ ).

Table I Age distribution of subjects

\begin{tabular}{llll}
\hline Age (years) & Study group & Control group & Total \\
\hline$<20$ & 0 & $\mathrm{I}$ & $\mathrm{I}$ \\
$20-24$ & 3 & 6 & 9 \\
$25-29$ & 9 & 2 & $\mathrm{II}$ \\
$30-34$ & 15 & 7 & 22 \\
$35-39$ & 9 & 6 & 15 \\
$40-44$ & 9 & 6 & 15 \\
$45-49$ & 4 & $\mathrm{I}$ & 5 \\
$\geq 50$ & 3 & $\mathrm{I}$ & 4 \\
Total & 52 & 30 & 85 \\
Mean & $35.19 \pm 7.94$ & $33.77 \pm 9.15$ & $34.70 \pm 8.4$ \\
\hline
\end{tabular}

Note: $P=0.461$.
Table 2 Mean hemoglobin concentration, packed cell volume, red cell indices, serum iron, serum ferittin, and serum transferrin receptors according to gender

\begin{tabular}{lllll}
\hline & $\begin{array}{l}\text { Women } \\
(\mathbf{n}=\mathbf{3 2})\end{array}$ & $\begin{array}{l}\text { Men } \\
(\mathbf{n}=\mathbf{5 0})\end{array}$ & $\begin{array}{l}\text { Total } \\
(\mathbf{n}=\mathbf{8 2})\end{array}$ & P value \\
\hline $\mathrm{Hb}(\mathrm{g} / \mathrm{dL})$ & $12.48 \pm 2.30$ & $13.80 \pm 1.69$ & $13.29 \pm 2.04$ & 0.004 \\
$\mathrm{PCV}(\%)$ & $39.00 \pm 6.66$ & $42.57 \pm 5.6 \mathrm{I}$ & $41.18 \pm 6.25$ & $0.01 \mathrm{I}$ \\
$\mathrm{MCV}(\mathrm{fl})$ & $82.35 \pm 8.04$ & $82.30 \pm 7.04$ & $82.32 \pm 7.39$ & 0.977 \\
$\mathrm{MCH}(\mathrm{Pg})$ & $27.08 \pm 3.25$ & $28.53 \pm 8.36$ & $27.97 \pm 6.84$ & $0.35 \mathrm{I}$ \\
$\mathrm{MCHC}(\mathrm{g} / \mathrm{dL})$ & $32.13 \pm 1.82$ & $32.32 \pm 2.00$ & $32.25 \pm 1.92$ & 0.658 \\
Serum iron & $10.34 \pm 3.64$ & $12.26 \pm 4.20$ & $\mathrm{II} .53 \pm 4.08$ & 0.042 \\
$(\mu \mathrm{m} / \mathrm{L})$ & & & & \\
Serum ferritin & $40.41 \pm 32.13$ & $78.24 \pm 75.40$ & $63.30 \pm 64.48$ & 0.009 \\
$(\mathrm{ng} / \mathrm{mL})$ & & & & \\
sTfR $(\mu \mathrm{g} / \mathrm{mL})$ & $1.47 \pm 1.04$ & $1.39 \pm 0.52$ & $\mathrm{I} .42 \pm 0.76$ & 0.650 \\
\hline
\end{tabular}

Abbreviations: $\mathrm{Hb}$, hemoglobin; sTfR, serum transferrin receptor; PCV, packed cell volume; $\mathrm{MCV}$, mean cell volume; $\mathrm{MCH}$, mean corpuscular hemoglobin; $\mathrm{MCHC}$, mean corpuscular hemoglobin concentration.

A comparison of mean hemoglobin, packed cell volume, mean serum iron, mean serum ferritin, and mean serum transferrin receptor levels in the study and control groups is shown in Table 3. Mean hemoglobin in the study group $(13.47 \pm 2.36 \mathrm{~g} / \mathrm{dL})$ was not significantly higher than in the control group (12.98 $\pm 1.30 \mathrm{~g} / \mathrm{dL}, P=0.303)$. Similarly, even though the mean packed cell volume for the study group $(42.00 \% \pm 7.10 \%)$ was higher than in the control group $(39.76 \% \pm 4.14 \%)$, the difference did not reach statistical significance $(P=0.119)$. Mean cell volume was significantly lower in the study group $(80.49 \pm 7.44 \mathrm{fl})$ than in the control group $(85.49 \pm 6.25 \mathrm{fl}, P=0.003)$, but mean serum iron in the study group $(11.58 \pm 4.53 \mu \mathrm{m} / \mathrm{L})$ was not different from that in the control group $(11.44 \pm 3.18 \mu \mathrm{m} / \mathrm{L}, P=0.884)$. However, mean serum ferritin in the control group $(102.46 \pm 80.26 \mathrm{ng} / \mathrm{mL})$ was higher than in the study group $(41.46 \pm 40.33 \mathrm{ng} / \mathrm{mL})$ and this difference was statistically significant $(P=0.001)$. The mean

Table 3 Mean hemoglobin concentration, packed cell volume, red cell indices, serum iron, serum ferritin, and serum transferrin receptor levels in the study and control groups

\begin{tabular}{lccc}
\hline & $\begin{array}{l}\text { Study group } \\
(\mathbf{n}=\mathbf{5 2})\end{array}$ & $\begin{array}{l}\text { Control group } \\
(\mathbf{n}=\mathbf{3 0})\end{array}$ & P value \\
\hline $\mathrm{Hb}(\mathrm{g} / \mathrm{dL})$ & $13.47 \pm 2.36$ & $12.98 \pm 1.30$ & 0.303 \\
$\mathrm{PCV}(\%)$ & $42.00 \pm 7.10$ & $39.76 \pm 4.14$ & 0.119 \\
$\mathrm{MCV}(\mathrm{fl})$ & $80.49 \pm 7.44$ & $85.49 \pm 6.25$ & 0.003 \\
$\mathrm{MCH}(\mathrm{Pg})$ & $27.78 \pm 8.42$ & $28.30 \pm 2.42$ & 0.743 \\
$\mathrm{MCHC}(\mathrm{g} / \mathrm{dL})$ & $31.91 \pm 2.19$ & $32.83 \pm 1.15$ & 0.036 \\
Serum iron $(\mu \mathrm{m} / \mathrm{L})$ & $11.58 \pm 4.53$ & $11.44 \pm 3.18$ & 0.884 \\
Serum ferritin $(\mathrm{ng} / \mathrm{mL})$ & $41.46 \pm 40.33$ & $102.46 \pm 80.26$ & 0.001 \\
sTfR $(\mu \mathrm{g} / \mathrm{mL})$ & $1.56 \pm 0.88$ & $1.19 \pm 0.41$ & 0.033 \\
\hline
\end{tabular}

Abbreviations: $\mathrm{Hb}$, hemoglobin; sTfR, serum transferrin receptor; PCV, packed cell volume; $\mathrm{MCV}$, mean cell volume; $\mathrm{MCH}$, mean corpuscular hemoglobin; $\mathrm{MCHC}$, mean corpuscular hemoglobin concentration. 
serum transferrin receptor value was also significantly higher in the study group $(1.56 \pm 0.88 \mu \mathrm{g} / \mathrm{mL})$ than in the control group $(1.19 \pm 0.41 \mu \mathrm{g} / \mathrm{mL}, P=0.033)$.

Table 4 shows a comparison of mean serum iron, ferritin, and transferrin receptor levels according to gender in the study group and the control group. In both groups, women had a lower mean serum iron but this was not statistically significant. However, in the study group, women had significantly lower mean serum ferritin levels $(28.02 \pm 25.00 \mathrm{ng} / \mathrm{mL})$ than men $(48.57 \pm 45.17 \mathrm{ng} / \mathrm{mL}, P=0.040)$. Similarly, in the control group, women had significantly lower mean serum ferritin levels $(56.35 \pm 34.03 \mathrm{ng} / \mathrm{mL})$ than men (145.49 $\pm 87.74 \mathrm{ng} / \mathrm{mL}, P=0.000)$. Women in the study group also had significantly lower serum ferritin levels $(28.02 \pm 25.00 \mathrm{ng} / \mathrm{mL})$ than women in the control group $(56.35 \pm 34.03 \mathrm{ng} / \mathrm{mL}, P=0.014)$. Similarly, men in the study group had significantly lower mean ferritin levels $(48.57 \pm 45.17 \mathrm{ng} / \mathrm{mL})$ than men in the control group $(145.49 \pm 87.74 \mathrm{ng} / \mathrm{mL}, P=0.000)$. The mean serum transferrin receptor level in the control group was also expectedly higher in women $(1.22 \pm 0.44 \mu \mathrm{g} / \mathrm{mL})$ than in men $(1.15 \pm 0.39 \mu \mathrm{g} / \mathrm{mL})$. However, this difference did not reach statistical significance $(P=0.650)$. In the study group, women did not have significantly higher mean serum transferrin receptor levels $(1.66 \pm 1.32 \mu \mathrm{g} / \mathrm{mL})$ compared with men $(1.50 \pm 0.55 \mu \mathrm{g} / \mathrm{mL}, P=0.625)$. Women in the study group also had a higher mean serum transferrin receptor level $(1.66 \pm 1.32 \mu \mathrm{g} / \mathrm{mL})$ compared with women in the control group $(1.22 \pm 0.44 \mu \mathrm{g} / \mathrm{mL}, P=0.196)$, but again the

Table 4 Mean serum iron, ferritin, and serum transferrin receptors (sTfR) in study and control groups segregated according to gender

\begin{tabular}{llll}
\hline & $\begin{array}{l}\text { Serum iron } \\
(\mu \mathrm{m} / \mathrm{L})\end{array}$ & $\begin{array}{l}\text { Serum ferritin } \\
(\mathrm{ng} / \mathrm{mL})\end{array}$ & $\begin{array}{l}\mathbf{s T f R} \\
(\mu \mathrm{g} / \mathrm{mL})\end{array}$ \\
\hline $\begin{array}{l}\text { Study group } \\
\text { Females }(\mathrm{n}=18)\end{array}$ & $10.41 \pm 4.15$ & $28.02 \pm 25.00$ & $1.66 \pm 1.32$ \\
Males $(\mathrm{n}=34)$ & $12.16 \pm 4.65$ & $48.57 \pm 45.17$ & $1.50 \pm 0.55$ \\
Total $(\mathrm{n}=52)$ & $11.58 \pm 4.53$ & $41.46 \pm 40.33$ & $1.56 \pm 0.88$ \\
Control group & & & \\
Females $(\mathrm{n}=14)$ & $10.25 \pm 3.00$ & $56.35 \pm 34.03$ & $1.22 \pm 0.44$ \\
Males $(\mathrm{n}=16)$ & $12.47 \pm 3.06$ & $145.49 \pm 87.74$ & $1.15 \pm 0.39$ \\
Total $(\mathrm{n}=30)$ & $11.44 \pm 3.18$ & $102.46 \pm 80.26$ & $1.19 \pm 0.4$ \\
$\boldsymbol{P}$ values & & & \\
$*$ & 0.171 & 0.040 & 0.625 \\
$* *$ & 0.055 & 0.000 & 0.650 \\
$* * *$ & 0.900 & 0.014 & 0.196 \\
$* * * *$ & 0.780 & 0.000 & 0.013 \\
\hline
\end{tabular}

Notes: *Study women versus study men; **control women versus control men; ***study women versus control women; ****study men versus control men. Abbreviation: sTfR, serum transferrin receptor. difference was not statistically significant. However, men in the study group had a significantly higher mean serum transferrin receptor level $(1.50 \pm 0.55 \mu \mathrm{g} / \mathrm{mL})$ compared with men in the study group $(1.15 \pm 0.39 \mu \mathrm{g} / \mathrm{mL}, P=0.013)$.

\section{Discussion}

Blood banks have a responsibility to protect blood donors and prevent them against developing anemia. They also have an important role to play in encouraging voluntary blood donation in a society like Nigeria where blood donation is viewed with skepticism.

In this study, there was no significant difference in hemoglobin concentration between regular blood donors and firsttime donors ( $P=0.303$ and $P=0.119$, respectively). This is similar to the observations of Flesland et al, who reported that the hemoglobin concentration in regular blood donors was not significantly different from that in first-time donors. ${ }^{13}$ Similarly, Szymczy-Nuzka and Woloweic reported a normal hemoglobin and packed cell volume in 151 regular male donors who had given over ten units of whole blood at a frequency of 4-6 units per year. ${ }^{14}$ Denicourt and Goudemand also found no significant difference in hemoglobin and packed cell volume in 394 women who had given three donations yearly for 2-10 years, compared with new donors. ${ }^{15}$ Further, several studies have reported no cases of anemia in male and female donors donating $1700-3100 \mathrm{~mL}$ of blood annually, ${ }^{16,17}$ but this finding is in contrast with the work of Djalali et al, ${ }^{18}$ as well as that of Zaccheus and Baribefe, ${ }^{19}$ who reported a significantly lower hemoglobin and packed cell volume in regular blood donors when compared with healthy controls.

In our study, the mean serum ferritin level was significantly lower in the study group than in the control group $(P=0.000)$. Szymczyk-Nuzka and Woloweic, when determining the prevalence of iron deficiency in regular blood donors, noted a lower serum ferritin level in this group in contrast with first-time donors who had normal serum ferritin levels. ${ }^{14}$

Studying iron stores in Nigerian blood donors, Usanga noted significantly lower ferritin levels in regular blood donors compared with healthy controls, ${ }^{20}$ and suggested that some regular blood donors may have prelatent or latent iron deficiency at the time of donation. Norashikin et al also reported significantly lower serum ferritin levels in regular blood donors. ${ }^{21}$ However, Vilzu et al found no significant difference between ferritin levels in controls and donors donating less than 20 units. ${ }^{22}$ Several researchers have noted a significant reduction in ferritin levels with increasing donations. . $^{19,21-25}$ 
Even though we reported a lower serum ferritin level with increasing number of donations, this pattern failed to reach statistical significance, which may reflect the small sample size or be due to increased iron absorption subsequent to a compensatory increase in hemopoiesis in the face of tightly regulated loss.

The lack of a statistically significant difference in mean serum iron between the study and control groups is consistent with the results of a study by Akpotuzor et $\mathrm{al}^{26}$ who concluded that there was no observable difference in biochemical iron parameters between regular donors and healthy controls. In contrast, several other studies have documented lower serum iron levels in regular blood donors compared with healthy controls. ${ }^{19}$ In order to determine the usefulness of serum iron and ferritin for accurate diagnosis of iron deficiency in hospital patients, Burns et $\mathrm{al}^{27}$ compared the results of serum iron and ferritin with the presence of stainable iron in bone marrow aspirates from 301 patients. Using standard criteria, iron deficiency was correctly diagnosed by serum iron in only $41 \%$ and ferritin in $90 \%$ of patients, respectively. These investigators concluded that iron measurements lack the prerequisite sensitivity and/or specificity for accurate diagnosis of iron deficiency.

\section{Conclusion}

Our data suggest that hemoglobin concentration, packed cell volume, and serum iron levels are not significantly affected by regular blood donation. Regular blood donors appear to have reduced iron stores when compared with nondonors, as shown by significantly reduced serum ferritin levels and raised serum transferrin receptor levels. A larger study should be carried out to confirm these preliminary findings.

\section{Disclosure}

The authors report no conflicts of interest in this work.

\section{References}

1. World Health Organisation. Management of blood transfusion services. 1990. Available from: http://www.who.int. Accessed November 22, 2009.

2. Halliwell B, Gutteridge JMC. Role of free radicals and catalytic metal ions in human disease: an overview. Meth Enzymol. 1990;186:1-85.

3. Sullivan JL. Iron and the sex difference in heart disease risk. Lancet. 1981;1:1293-1294.

4. Sullivan JL. Are menstruating women protected from heart disease because of, in spite of, estrogen? Relevance to iron hypothesis. Am Heart J. 2003;145:190-194.

5. Pratico D, Pasin M, Barry OP, et al. Iron-dependent human platelet activation and hydroxyl radical formation; involvement of protein kinase C. Circulation. 1999;99:3118-3124.
6. Penn MS, Cui M-Z, Winokur AL, et al. Smooth muscle cell surface tissue factor pathway activation by oxidised low-density lipoprotein requires cellular lipid peroxidation. Blood. 2000;96:3056-3063.

7. Salonen JT, Nyyssonen K, Korpella H, et al. High stored iron levels are associated with excess risk of myocardial infarction in Eastern Finnish men. Circulation. 1992;86:803-811.

8. Russo G, Leopold JA, Loscalzo J. Vasoactive substances: nitric oxide and endothelial dysfunction in atherosclerosis. Vasc Pharmacol. 2002;38:259-269.

9. Zheng H, Cable R, Spencer B, Votto N, Katz SD. Iron store and vascular function in voluntary blood donors. Arterioscler Thromb Vasc Biol. 2005;25:1577-1583.

10. Duffy SJ, Biegelsen ES, Holbrook M, et al. Iron chelation improves endothelial function in patients with coronary artery disease. Circulation. 2001;103:2799-2804.

11. Morrison HI, Semenciw RM, Mao Y, Wigle DT. Serum iron and risk of fatal acute myocardial infarction. Epidemiology. 1994;5: 243-246.

12. Kiechl S, Willeit J, Egger G, Poewe W, Oberhollenzer F. Body iron stores and the risk of carotid atherosclerosis: prospective results from the Bruneck study. Circulation. 1997;96:3300-3307.

13. Flesland $O$, Eskelund AK, Flesland AB, et al. Transferrin receptors in serum. A new tool in the diagnosis and prevention of iron deficiency in blood donors. Transfus Apher Sci. 2004;31:11-16.

14. Szymczyk-Nuzka M, Wolowiec D. Iron stores in regular blood donors. Pol Arch Med Wewn. 2003;110:1415-1421.

15. Denicourt L, Goudemand M. Hypochromic anaemia and female blood donors. Transfusion. 1964;7:151-160.

16. Olsson KS. Iron stores in normal men and male blood donors as measured by desferrioxamine and quantitative phlebotomy. Acta Med Scand. 1972;192:401-407.

17. Spielman W, Gathof A, Kopp H. Studies of iron and protein metabolism in permanent blood donors. Munch Med Wochenschr. 1958;100: 183-187.

18. Djalali M, Neyestani TR, Bateni J, Siassi F. The effect of repeated blood donations on the iron status of Iranian blood donors attending the Iranian blood transfusion organization. Int J Vitam Nutr Res. 2006;76: 132-137.

19. Zaccheus AJ, Baribefe BK. Anaemia, iron deficiency and iron deficiency anaemia among blood donors in Port Harcourt Nigeria. Blood Trans. 2010;8:113-117.

20. Usanga EA. Iron stores of Nigerian blood donors as assessed by serum ferritin concentration. Cent Afr J Med. 1990;36:170-173.

21. Norashikin J, Roshan TM, Rosline H, et al. A study of serum ferritin levels among male blood donors in hospital University Sains Malaysia. Southeast Asian J Trop Med Public Health. 2006;37:370-373.

22. Vilsu I, Apksha B, Snehalata C. Iron status of regular voluntary blood donors. Asian J Transfus Sci. 2008;2:9-12.

23. Ahmed SG, Gwarzo AK. Risk factors for post donation syncope among blood donors in Nigeria. The Internet Journal of Third World Medicine. 2007:4(2). Available from: http://archive.ispub.com/journal/ the-internet-journal-of-third-world-medicine/volume-4-number-2/ risk-factors-for-post-donation-syncope-among-blood-donors-in-nigeria.html\#sthash.29FV9D31.dpbs. Accessed March 8, 2010.

24. Berde B, Hollander L, Undritz E, Zehnder K. Serum iron in blood donors. Schweiz Med Wochenschr. 1955;85:936-939. German.

25. Milman N. Serum ferritin in Danes: studies of iron status from infancy to old age, during blood donation and pregnancy. Int J Hematol. 1996;63: $103-135$.

26. Akpotuzor JO, Isong C, Okpokam DC, Etukudo MH. Levels of serum iron, TIBC, transferrin saturation and PCV in blood donors in Calabar Cross Rivers State, Nigeria. Pakistan Journal of Nutrition. 2008;7: 500-502.

27. Burns ER, Goldberg SN, Lawerence C, Wenz B. Clinical utility of serum tests for iron deficiency in hospitalized patients. Am J Clin Pathol. 1990; 93:240-245. 
Journal of Blood Medicine

\section{Publish your work in this journal}

The Journal of Blood Medicine is an international, peer-reviewed, open access, online journal publishing laboratory, experimental and clinical aspects of all topics pertaining to blood based medicine including but not limited to: Transfusion Medicine; Blood collection, Donor issues, Transmittable diseases, and Blood banking logistics; Immunohematology; Artificial and alternative

Submit your manuscript here: http://www.dovepress.com/Journal-of-blood-medicine-journal

blood based therapeutics; Hematology; Biotechnology/nanotechnology of blood related medicine; Legal aspects of blood medicine; Historical perspectives. The manuscript management system is completely online and includes a very quick and fair peer-review system. Visit http://www.dovepress.com/ testimonials.php to read real quotes from published authors. 